\title{
Public Participation of the River Chief System in China: Current Trends, Problems, and Perspectives
}

\author{
Chenhui $\mathrm{Wu}^{1}{ }^{1} \mathbb{D}$, Maosen $\mathrm{Ju}^{2, *}$, Longfei Wang ${ }^{3}$, Xiangyi Gu ${ }^{4}$ and Cuiling Jiang ${ }^{1}$ \\ 1 College of Hydrology and Water Resources, Hohai University, Nanjing 210098, China; \\ chwu@hhu.edu.cn (C.W.); jiangcuiling@hhu.edu.cn (C.J.) \\ 2 Research and Training Center for River Chief System, Hohai University, Nanjing 210098, China \\ 3 College of Environment, Hohai University, Nanjing 210098, China; lfwang@hhu.edu.cn \\ 4 School of Law, Hohai University, Nanjing 211100, China; guxiangyi@hhu.edu.cn \\ * Correspondence: maosenju@hhu.edu.cn
}

Received: 30 October 2020; Accepted: 10 December 2020; Published: 12 December 2020

\begin{abstract}
The River Chief System (RCS) is an effective measure for China to solve complex water problems and maintain the health of rivers and lakes. It is an institutional innovation to improve the water governance system and ensure national water security. Guiding and encouraging the public to participate in the construction of the RCS can promote the improvement of the level of social governance. The RCS is an effective supplement and supervision to the performance of the river chief and related departments, which can effectively promote the transformation of the RCS from nominal to practical and efficient. This study summarizes the innovative models and practical effects of, and public participation in, the RCS, analyzes the prominent problems, and proposes some measures to maximize the influence of public participation. The study provides insights on how to ensure the long-term operation of the RCS, a reference for countries around the world as a suitable solution for the sustainable management of water environments.
\end{abstract}

Keywords: River Chief System; public participation; collaborative governance; sustainable management; watershed management

\section{Introduction}

With the acceleration of industrialization and urbanization in the past four decades, rivers and lakes in China are under severe and complex pressure from pollution, and the water management system is also undergoing tremendous changes. China has pursued the integrated water resources management (IWRM) approach since enacting its first Water Law in 1988. IWRM is a process that promotes the coordinated development and management of water, land, and related resources in order to maximize economic and social welfare without compromising the sustainability of vital ecosystems [1]. Nonetheless, IWRM does not mean centralized management of a department but is coordinated and managed by various departments including the Ministry of Water Resources, the Ministry of Housing and Urban-rural Development, the Ministry of Environmental Protection, and the Ministry of Transportation, etc. Complex problems exist in interregional, intergovernmental, and inter-departmental collaboration in water resources management, which reduces the coordination of water resources and water environment management. The inefficiency of the IWRM and the difficulty implementing it in China may be ascribed to factors including amorphous definition, operational difficulty, departmental conflicts, and lack of authority in river basin management [2]. China's water governance capacity still has not reached the level of extensive governance to refined governance compared to that in European countries after industrial civilization. There is a lack of public participation in the decision-making process, leading to information asymmetry. The Chinese 
government has been facing three challenges of modern supervision, ecological protection, and spatial planning. There is no corresponding connection and systematic consideration in the information level nor in the administrative system. Therefore, policies such as the EU Water Framework Directive that have been implemented in developed countries have not found appropriate applications in China. Although China has conducted various water management explorations in the past, in the face of a severe water crisis and failure of IWRM, the Chinese government has to adopt a top-down design to reform the water management system.

In August 2007, to address the large-scale, blue-green algae outbreak in Taihu Lake, Wuxi City took the lead in implementing the River Chief System (RCS) in China. The RCS is an institutional innovation to address China's complex water problems and ensure national water security. Since then, the RCS has been used as an alternative approach to previous water management methods and has been gradually promoted in various provinces. At the end of June 2018, 31 provinces (including natural provinces, autonomous regions, and municipalities) across the country had fully established the RCS, and each river had been nominated with at least one river chief. The state and local governments have successively formulated regulations and normative documents to provide specific details on the promotion and implementation of the RCS from a legal perspective, as shown in Figure 1. The success of RCS is rooted in China's national conditions [2]. The river chief is held by the main leaders of the party and government, solving the predicament of multi-governance [3] and linking with the performance appraisal [4], which is conducive to the coordination and integration of resources from all parties, thereby maximizing the cohesion of water governance [5].

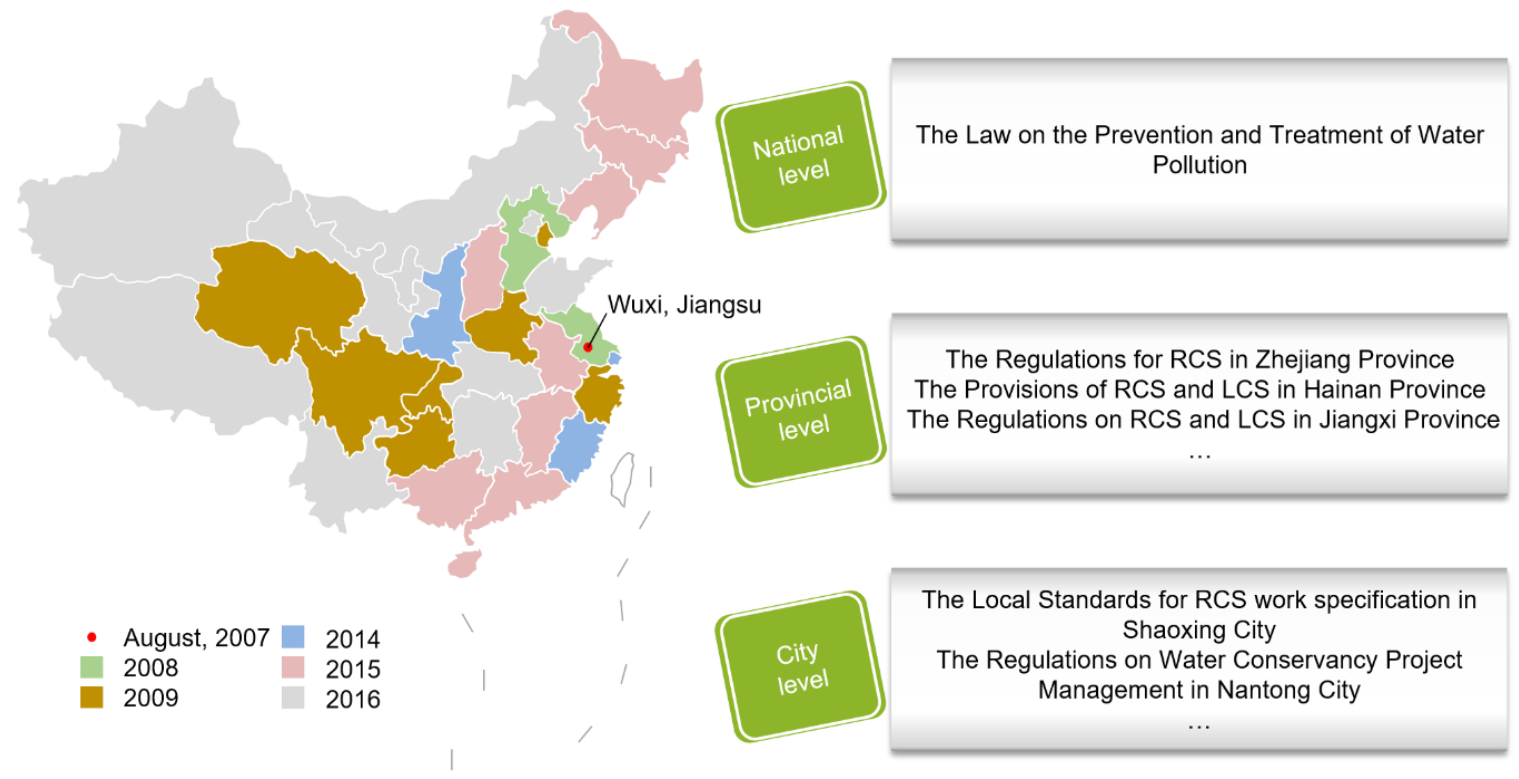

(a)

(b)

Figure 1. (a) Policy diffusion of the River Chief System (RCS) from 2007 to 2016; (b) Regulations and normative documents of the RCS at various administrative levels. (Source: official website and media of each provincial government).

Since the implementation of the RCS, significant results have been achieved. The water governance index (integrating the five dimensions of resources, society, economy, ecology, and environment) increased from 0.468 in 2010 to 0.691 in 2015 and is expected to exceed 0.857 in 2020 [6]. Through the analysis of a differential game model [7] and the difference-in-difference method [8], it was found that the effect of water pollution control is significant. The RCS has gradually changed from an emergency to a standard policy. The full implementation of the RCS has become an inherent requirement for China to effectively solve complex water problems, to implement the concept of green development, and to promote the construction of ecological civilization. The water bodies involved in the RCS are 
not limited to rivers, lakes, and reservoirs, but also small water bodies such as ditches, canals, streams, and ponds, and it is thus difficult for the river chief to control them all. The local public is more familiar with small water bodies, and public participation can greatly improve work efficiency.

As an important social force, public participation is gradually breaking the original pattern of "active government, passive enterprise, and inactive public" in river and lake governance [9]. Polany first proposed the concept of "polycentric" social order in 1951 [10]. After that, the Ostroms provided empirical evidence and formed the theory of social governance, advocating that active public policies should fully and effectively reflect the wishes, needs, and interests of all classes of society. Mills first proposed the theory of public participation in the 1950s, believing that the public should be given more power to participate in decision-making to break through the traditional closed government decision-making and management systems [11]. Arnstein detailed the degree of public participation by dividing it into three types (nonparticipation, degrees of tokenism, degrees of citizen power) and eight steps (manipulation, therapy, informing, consultation, placation, partnership, delegated power, citizen control) in 1969 [12]. His research is important for guiding how to improve public participation awareness and enhance participation behavior. Freeman defines "stakeholders" as any individuals or groups who can affect or are affected by the achievement of an organization's objective [13]. Therefore, the organization pursues the overall interests of stakeholders, not just the interests of a certain subject. When stakeholders are directly or indirectly affected by a certain decision, they should participate in the decision-making process in a timely, effective, and direct manner. In the process of comprehensive river regulation, the public is directly affected by the relevant systems and construction, and is a direct stakeholder, so they have the right and obligation to participate in it.

Many countries around the world have accumulated practices and successful experience in environmental public governance. The U.S. Congress passed the Tennessee Valley Authority Act in 1933 and established the Tennessee Valley Authority to support public participation in river basin management [14]. In response to funding cuts that have prevented many agencies from comprehensive environmental monitoring, Canada has given a role to community-based water monitoring organizations that provide missing data [15]. The EU Water Framework Directive calls on the public to actively participate in water governance. A comparative analysis of the cases of Germany, the United Kingdom, and Spain by Euler et al. shows that with an increase of public awareness it is desirable to increase the public's participation in river basin management [16]. Ananga et al. concluded based on a study of the water supply system in Kenya that the authorities in Africa and other impoverished areas should facilitate citizen or community participation as a feasible cost-saving strategy to promote and protect the sanitary quality of drinking water [17]. The United Nations Economic Commission for Europe (UNECE) passed the Aarhus convention in 1998, which is a milestone in the development of the environmental information disclosure system, and can be signed by all member states of the UNECE and countries with consultative status with the UNECE, and regional economic integration organizations that meet certain conditions. The Aarhus Convention and Principle 10 Guidelines stipulate that people in all countries have access to information related to environmental protection and have full opportunities to participate in the decision-making process regarding environmental issues, which particularly impacted the public participation in the Philippines. There has been a growing number of cases of civil society advocacy and participation that have significantly impacted the decision processes of environmental policies and projects. The ability for citizens to participate in decision-making processes has been notably strengthened [18].

In the process of legalization in China, the public participation system has been endowed with multi-level legal and regulatory protection, which has been pushing the public to play new roles in environmental protection and social welfare [19]. According to the Environmental Information Disclosure Measures (for Trial Implementation) in 2007 [20], the environmental protection department shall actively disclose to society the distribution and implementation of the total emissions of major pollutants, the issuance of pollution permits, and the quantitative assessment results of comprehensive improvement of urban environments within the scope of their duties and powers, including the 
assessment results of river chief work. The newly revised Environmental Protection Law of the People's Republic of China [21] incorporated public participation into the basic principles in 2014 and detailed the related content of information disclosure and public participation, including the right to know, the right to participate, the right to supervise, and the right to litigate, thus enhancing the status of public participation. The Measures for Public Participation in Environmental Protection [22] and the Measures for Public Participation in Environmental Impact Assessment [23] were subsequently issued to provide specific institutional norms for public participation in collaborative environmental governance. In April 2015, the State Council issued the Action Plan for Prevention and Control of Water Pollution [24], which emphasized the need to strengthen public participation and social supervision. It specifically proposed that the government should provide the public and social organizations with training and consultation on water pollution prevention and control laws and regulations, encourage them to participate in environmental law enforcement and water pollution incident investigations throughout the process, improve the reporting system, and actively promote environmental public interest litigation. In December 2016, the General Office of the Central Committee of the Communist Party of China and the General Office of the State Council issued and implemented the Opinions on Full Implementation of the River Chief System [25], that expanded public participation channels in the basic principles and proposed specific measures to strengthen social supervision. This included establishing a river and lake management and protection information release platform and hiring social supervisors to supervise and evaluate the effects of river and lake management and protection. Therefore, the work of the RCS does not lack legal and regulatory support. Whether it can function well depends more on administrative pressure and incentive mechanisms of reward and punishment.

In China, government officials have public power only after being authorized by the People's Congress. The object of responsibility should be the people, and the subject of accountability to officials should also be the people [26]. The subjects of public participation in the RCS include but are not limited to mass media, experts, voluntary organizations, public interest lawyers, community organizations, and individual citizens. The essence of public participation is that to prevent the abuse of power and rent-seeking behaviors of government agencies in the implementation of policies, relevant interest groups will negotiate with government departments in terms of resource utilization and distribution, as well as social welfare establishment and operation, and supervise and evaluate the implementation of the policy. Hence, how to ensure valid public participation in the construction of the RCS, and to let the public experience a real sense of participation, and happiness, are important parts during the comprehensive strengthening of RCS.

The introduction describes the water management system in China and its problems in the past, which partially explains the reasons for the success of the RCS. Public participation has been confirmed as an important force in the water management and water environment governance of countries around the world. Therefore, we comprehensively collect the practical cases of public participation of the RCS in various parts of China. It first summarizes the innovation models of public participation in four aspects, i.e., supervision and management mode, participation working mechanism, social propaganda method, and incentive feedback mechanism. Second, it summarizes the practical effects of public participation in the RCS. Finally, it analyzes the existing problems of public participation in the RCS and puts forward suggestions for promotion. The aim is to provide a reference for the water environment management of various countries and promote the transformation of the RCS from nominal to practical and efficient.

\section{Methodology}

This research adopted a literature research method, field survey method, and case analysis method as the main methods. The literature included researches on public participation in water management and the RCS at home and abroad. In addition to the literature review, we have carried out a large number of field investigations and case collection works. 
On April 28, 2017, with the support from the Ministry of Water Resources, the "Research and Training Center for River Chief System in Hohai University" was established. The author team of this study is an important member of the center, which serves as an open cooperation platform specializing in the scientific research and talent training of the RCS. It provides comprehensive and multi-channel services for the full implementation of the RCS by uniting domestic and foreign resources and scientific research forces of the university. For example, it had already conducted more than 80 courses training the river (lake) chiefs at various administrative levels for the Organization Department of the Central Committee, the Ministry of Water Resources, and various provinces. Up to now, the center has organized 7 academic forums or conferences and has trained nearly 20,000 river (lake) chiefs and technical personnel at all administrative levels across the country.

Serving as the person in charge of the Research and Training Center as well as the corresponding author of the paper, Prof. Ju has been organizing various training programs and RCS implementation cases, constituting a proportion of case studies listed in the following part of the manuscript. We had the opportunity to meet and discuss the operation of the RCS with government officials, the local public, and representatives of water environmental management companies across the country. We were often invited to visit the rivers where the RCS was implemented. We cogitated the operation of public participation in the RCS through observation, comparison, and discussion.

\section{Innovative Models of Public Participation in the RCS}

\subsection{Innovation of Supervision and Management Mode}

\subsubsection{Civilian River Chief}

The Opinions on Full Implementation of the River Chief System stipulates that the river chief shall be held by the main party and government leaders at all levels. Its tasks include strengthening the following: water resource protection, river and lake shoreline management and protection, water pollution prevention, water environment governance, water ecology restoration, and law enforcement and supervision. Compared with the administrative river chief who is tasked with daily work, the civilian river chief is more flexible. The civilian river chief first appeared in the policy of Five Water Treatment in Zhejiang Province, and then many provinces and cities formulated corresponding management systems. This strengthened the standardized construction and management of the civilian river chief. For example, Changzhou City, Jiangsu Province, issued the Implementation Opinions on Establishing a Civilian River Chief System in the City in 2018, which stipulates that the city, district, and town levels recruit and manage civilian river chiefs at all levels, to achieve unified management of registration and orderly dispatch. Xiangtan City, Hunan Province, formulated the Xiangtan "Civilian River Chief" Management Measures (Trial) in 2018 to clarify the scope of work of the civilian river chief, including assisting the river chief to supervise the law enforcement actions of relevant law enforcement agencies. In 2019, Hebei Province established a civilian river chief organization system with provincial-level regulatory authorization, group-level management, and river chiefs performing duties following regulations, clarifying the responsibilities and prohibited behaviors of the civilian river chief, and organizing relevant business training.

The service forms of the civilian river chief across the country are also continuously innovating. In 2017, Haimen City, Jiangsu Province, established the aunt river chief (an experienced female river chief who plays a role in community management), produced a publicity sign with the aunt's cartoon image, and opened a river chief course for the aunt river chief to exchange their daily experience. In 2018, Suqian City, Jiangsu Province, elected a group of retired teachers, party members, and cadres with recognized character, talent, and fame from towns and villages in 2018 to form the township river chief who is responsible for the care of small water bodies. In 2019, the Gulou District Government of Nanjing City, Jiangsu Province, hired 24 experts and scholars from Hohai University to serve as expert river chiefs for 24 district-level rivers to provide scientific and technological support, intellectual support for river and lake management, and the formulation of the "One River, One Policy" plan. In 2019, 
Nanchong City, Sichuan Province, with the approval of the Civil Affairs Department, established the reporter river chief association, which absorbed 53 reporters and carried out the promotion and supervision of the RCS in 9 counties. Other civilian river chiefs include academician, cross-border union, foreigner, campus, media, and network.

\subsubsection{Voluntary Organizations}

Volunteer organizations are the backbone of public participation in river and lake governance and can provide organized channels for public participation. In 2014, Zhejiang Province issued the Guiding Opinions on Carrying out the Voluntary Service Activities of the "Five Water Treatment" in the whole province, organized a team of water conservancy volunteers, carried out public welfare activities, strengthened public participation, and further clarified the development of "Five Water Treatment" voluntary services of the significance, guiding ideology, working ideas, form and content, role play, institutional mechanisms, and normalized development. In 2018, Wuxi City, Jiangsu Province, established a river protection volunteer team. The River Chief Office contracted the river sections to outstanding party members and community members. Several volunteer teams, such as the street party members' volunteer team for protecting the river and the Love River "Woodpecker" team, have been established and carried out activities, such as regular water protection inspections, civilized supervision, and water conservancy lectures. In 2019, Mianyang City, Sichuan Province, mobilized village cadres, enterprise representatives, retired cadres, and people who are enthusiastic about public welfare undertakings to form 22 self-governing river management and protection associations, which relied on the village self-governing convention, carried out river management and protection work, and actively guided community members to implement group management of rivers. Others include the Green Water Guardians Association, the River Watchers, the Red Scarf Little River Chief Volunteer Service Team, and the Mo Chou Environmental Protection Association.

\subsubsection{Social Supervisor}

The establishment of social supervisors can improve the supervision system of the RCS, improve the working style of river chiefs, and make them more willing to accept social supervision. In 2018, Wujiang District, Suzhou City, Jiangsu Province, mobilized through paper media, WeChat, etc., openly recruited 47 enthusiastic people to become civil society supervisors. They participated in river inspection, management, and protection with People's Congress representatives, party representatives, People's Political Consultative Conference members, and volunteer teams forming a comprehensive and multi-level RCS work supervision network. In 2018, Tianjin City issued the Measures for the Appointment and Management of Municipal-level Social Obligation Supervisors of the River (Lake) Chief System in Tianjin, and publicly recruited 160 municipal-level social obligatory supervisors. The evaluation of water management and protection is included in the monthly assessment of the RCS. The 33 social supervisors who cannot serve as supervisors are re-recruited in the following year to fully guarantee the public's supervisory role in the management and protection of rivers and lakes. In 2019, the AVIC Radar and Electronic Equipment Research Institute of Wuxi City, Jiangsu Province, signed an agreement with the Wuxi Happy Volunteer Environmental Protection Association to recruit 50 volunteers to serve as river water quality supervisors, who regularly check and report on the river environment and sensory conditions of water quality. Other examples include river-protecting scouts, and river and lake inspectors.

\subsection{Innovation of Participation Working Mechanisms}

\subsubsection{Billboard of the RCS}

The Opinions on Full Implementation of the River Chief System stipulates that social supervision should be strengthened, and a billboard of the RCS should be erected at a prominent position on the banks of rivers and lakes, indicating the responsibilities of the river chief, the general situation of the 
river and lake, the management and protection objectives, and the supervision telephone number. The billboard of the RCS is a publicity board to show the work of the RCS to society. In addition to the main content mentioned above, some also have a QR code. The public can understand the progress of river governance and related policies and regulations, "One River, One Policy," by scanning the code. This can reflect the quality and effectiveness of the RCS, and also in an important platform for the public to supervise the RCS.

\subsubsection{Collaborative Governance}

Collaborative governance can greatly enhance the awareness of public participation and improve the efficiency of the RCS. In 2018, the Water Conservancy Bureau of Wujiang District, Suzhou City, Jiangsu Province, and the District Post Office jointly launched the "Post Road of River Protection" project, using the wide distribution characteristics of the grass-roots postal network to allow 192 postmen record the management of rivers and lakes on the post road section during the daily delivery. In 2019, The River Chief Office of Zhumadian City, Henan Province, and the Municipal People's Procuratorate jointly formulated the Opinions on the Establishment of Public Interest Litigation Liaison Office to promote the effective connection between administrative law enforcement and justice, provide protection for the public to exercise litigation rights, and improve river and lake governance and management. Others include decision-making public participation in the governance of the rural water environment in Suzhou, the village consultation group model [27], and a large-scale weekend campaign to clean up rivers (lakes, reservoirs) in Huanggang City, Hubei Province since June 2018.

\subsubsection{RCS and Targeted Poverty Alleviation Linkage System}

Targeted poverty alleviation refers to a method that uses scientific procedures to accurately identify, assist, and manage poverty based on the environment in different poverty-stricken areas and the conditions of peasant households. The Chinese government has formally begun implementing targeted poverty alleviation since January 2015. The RCS and targeted poverty alleviation linkage system can effectively solve the problem of "how to help", make full use of the effectiveness of poverty alleviation resources, and enable the poverty alleviation targets to enjoy fair opportunities in market competition, rather than to indulge them blindly demanding and unsatisfied. The linked system not only maintains the continuity of targeted poverty alleviation but also guarantees fairness, greatly improving the enthusiasm for participation and living standards of poor households. In 2017, Jiangxi Province established the "River Chief System + Targeted Poverty Alleviation" system, hiring registered poverty alleviation targets as river cleaners or inspectors, and formed a long-term joint mechanism. At the same time, it expanded and deepened the "public welfare posts + poor households" model, put river cleaners into poverty alleviation jobs, and supported the "double no" poor households who had no employment and no industry but could engage in related public welfare work. This achieved a win-win situation for the environment and poor households. Through river cleaning, every poor person could escape poverty in one year. Sichuan Province also set up water conservancy project inspectors on a large scale in various poverty-stricken villages, mainly selected from the poor households that had registered. Other provinces have gradually formulated corresponding policies according to local conditions.

\subsection{Innovation of Social Propaganda Methods}

In addition to the billboard of the RCS, the government also carries out publicity for the RCS through newspapers, radio, television, the Internet, and other media. It also does so through activities such as essay competitions, civilized convention collection, theme publicity lectures, or through the selection superlatives (e.g., the most beautiful rivers and lakes, the most outstanding river chief, the most influential river protector). For example, in 2019, Wuzhong City, Ningxia Province, carried out the activities of the River (Lake) Chief System Work and the Promotion of the Construction of Beautiful Rivers and Lakes into Campus in schools around key river sections. They printed, purchased, 
and distributed brochures, such as River Chief System and Thanksgiving Nature, and reported through the county TV station and the river chief public platform. In 2019, Yangzhou City, Jiangsu Province, started a column titled River Chief in Action on the Yangzhou News column of the Yangzhou TV Station to further expand the influence of the RCS. Most provinces, cities, and counties have established WeChat official accounts for river chiefs to publicize the effectiveness of river and lake governance in various regions. In 2016, Shaoxing City, Zhejiang Province, innovatively started a column on the WeChat public account of the Shaoxing River Chief, providing an active platform for both residents and river chiefs sharing and talking about the river protection actions. It promoted the township river chief to talk about the experience in protecting the river, set up of the Beautiful Rivers and Lakes and Charm of Water program to promote the effectiveness of water governance, and developed a river patrol game in WeChat to publicize and educate [28]. Other examples include the construction of a river chief exhibition hall in Changxing County, Huzhou City, Zhejiang Province, and a river chief system theme park in Zhangjiagang City, Suzhou City, Jiangsu Province.

\subsection{Innovation of Incentive Feedback Mechanism}

The incentive feedback mechanism can fully mobilize the public's enthusiasm for participating in the RCS, and enhance public recognition and support for its implementation. The implementation of the RCS not only requires a detailed working mechanism but also should establish an incentive mechanism. It is necessary to solve the problem of "how to do it" as well as the problem of "do it well." To this end, a long-term river chief incentive system should be established. For those who take the initiative, perform their duties, and actively implement the RCS, all localities should combine actual conditions and give commendations and rewards following the regulations. For regions and departments that have made outstanding achievements in the management and protection of rivers and lakes, it is necessary to vigorously publicize and to highlight the exemplary role. In 2017, the Guangzhou Water Affairs Bureau specially launched the WeChat public account of Guangzhou Water Control Complaints. Citizens can report illegal activities or dirty rivers and lakes online and receive corresponding cash bonuses as long as they pass the verification. The reward rules are as follows: complaints about important new issues on workdays, up to RMB 10 yuan; up to RMB 15 yuan on holidays; up to RMB 5 yuan for reporting minor water pollution issues. Citizens with the top ten complaints per month can get a bonus ranging from RMB 30 to 100 yuan. In 2018, Deqing County, Huzhou City, Zhejiang Province, initiated the Ecological Green Currency mechanism. The public can obtain a certain amount of green currency by completing the task on the water protection platform. The exchange ratio of green currency to RMB is 10:1, which can be used at the designated exchange point for physical exchange, and also be exchanged for discounts in terms of a loan quota, loan interest rate, and guarantee method.

The above-mentioned cases are the typical innovative practices of public participation in the RCS in the country. Table 1 summarizes public participation of the RCS in provinces with different economic levels. For relatively more developed provinces such as Jiangsu, Zhejiang, and Guangdong, the local governments mainly focus on the exploration of the system and mechanism of the RCS. In addition, due to the frequent occurrence of water pollution and eutrophication in rivers and lakes, the government cannot guarantee the long-term cleanliness of rivers and lakes on its own. Therefore, local governments have been exploring various forms of public participation and have been constructing closer ties with the public. For less developed provinces with medium economic levels such as Hubei, Jiangxi, and Sichuan, the governments pay more attention to the practical exploration of the RCS and rely on it to increase the income of the people in poor areas. For Ningxia, where the economy is underdeveloped, the local government has been focusing on the propaganda of the RCS, owing to the still lacking awareness of the system. 
Table 1. Public Participation in the RCS in Provinces with Different Economic Levels.

\begin{tabular}{|c|c|c|}
\hline Economic level & Province & Practice \\
\hline \multirow[t]{3}{*}{ Developed } & Jiangsu & $\begin{array}{l}\text { - Changzhou City issued the Implementation Opinions on } \\
\text { Establishing a Civilian River Chief System in the City } \\
\text { - Nanjing City hired expert river chiefs; Haimen City established } \\
\text { the aunt river chief; Suqian City formed the township } \\
\text { river chief } \\
\text { - Wuxi City established several river protection volunteer teams } \\
\text { and recruited river water quality supervisors } \\
\text { - Wujiang District recruited civil society supervisors and } \\
\text { launched the "Post Road of River Protection" project; } \\
\text { Zhangjiagang City built a RCS theme park } \\
\text { - Yangzhou City started a propaganda column on the TV station }\end{array}$ \\
\hline & Zhejiang & $\begin{array}{l}\text { - Zhejiang Province issued the Guiding Opinions on Carrying } \\
\text { out the Voluntary Service Activities of the "Five } \\
\text { Water Treatment" } \\
\text { - Changxing County built a river chief exhibition hall } \\
\text { - Deqing County initiated the Ecological Green } \\
\text { Currency mechanism }\end{array}$ \\
\hline & Guangdong & $\begin{array}{l}\text { - Guangzhou City opened a complaint channel on its WeChat } \\
\text { official account }\end{array}$ \\
\hline \multirow{3}{*}{ Medium } & Hubei & $\begin{array}{l}\text { - Huanggang City launched a large-scale weekend campaign to } \\
\text { clean up rivers (lakes, reservoirs) }\end{array}$ \\
\hline & Jiangxi & $\begin{array}{l}\text { - Jiangxi Province established the "River Chief System + } \\
\text { Targeted Poverty Alleviation" system }\end{array}$ \\
\hline & Sichuan & $\begin{array}{l}\text { - Sichuan Province set up water conservancy project inspectors } \\
\text { on a large scale in various poverty-stricken villages }\end{array}$ \\
\hline Underdev-eloped & Ningxia & $\begin{array}{l}\text { Wuzhong City carried out publicity activities for RCS in } \\
\text { schools around key river sections }\end{array}$ \\
\hline
\end{tabular}

\section{Practical Effects of Public Participation of the RCS}

\subsection{Governance Effect}

With the deepening of the RCS, pollution sources have been effectively controlled, the public's awareness of environmental protection has increased, and participation has increased. Rivers and lakes have regained functions such as flood drainage, water regulation and storage, water supply and irrigation, recreation, and healthy ecology. Take Gaochun District, Nanjing City, Jiangsu Province, as an example. Referred to the National Environmental Quality Standards for Surface Water [29], the water quality of reservoirs and lakes in Gaochun District has improved significantly from 2017 to 2019, as shown in Table 2. In addition, the rates for reaching the qualified standard of 16 water function zones have been upgraded from $87.5 \%$ in 2017 to $100 \%$ in 2019 .

With the operation of the water system connection project, the poor quality of small water bodies in the countryside and insufficient governance directly affected Gucheng Lake. To this end, the Gaochun District River Chief Office promoted the civilian river chief system, strengthened the interaction between the government and the public, and jointly protected the water quality of the lake. Xiaocai Zhang from Gubai Street was a model representative of the civilian river chief and was known as the "leader of wealth." He was the head of a general aquaculture farm and had been dealing with water issues for a lifetime. The roles as civilian river chiefs further strengthened their sense of 
mission and enthusiasm for water ecological protection. After receiving relevant business training from the government, the civilian river chiefs have been setting up a communication bridge between the public and the government, strengthening propaganda authority, and enabling the follow-up work to be recognized and promoted smoothly. During the performance of his duty, Xiaocai Zhang not only actively promoted and managed, but also launched an outsourcing maintenance model around river governance, changing the government's water governance into collaborative water governance, passive water governance into active water governance, and establishing a long-term management and protection mechanism of "improving rivers by rivers." The mechanism was to focus on production on one hand and ecology on the other. It strictly forbids the use of aquaculture drugs during the whole breeding process and advocates natural restoration approaches such as snails and aquatic plants to mediate ecological balance. This mechanism also included a crab ecological breeding chain, effectively improved economic efficiency. First, the transformation from extensive breeding to intensive breeding has improved the quality of assets, management, and service, reducing the cost of breeding. Second, a standardized breeding standard for crabs in Gucheng Lake was formulated, including water quality conditions, fence setting, crab breeding, breeding management, etc., which reduced the costs for unregulated breeding. Third, in the past, the contractor only cared about breading processes but not the governance and management of the watershed environment. The government is responsible to formulate governance strategies and undertake the costs of the management. Hence, it was difficult to ensure governance efficiency and increased total costs. Alternatively, the contractor now undertakes the due obligations of watershed governance and management. An integrated bioremediation approach has been explored to improve the breading processes and the pollutant discharge has been much reduced, thus lightening the management costs. Fourth, crab breeding has promoted the fishing net industry in Xinzheng Village, Yangjiang Town, and the aquatic planting industry in Yaxi Village, Yaxi Town, and improved the economic benefits of the villagers. Xiaocai Zhang said that the aquaculture farm will continuously improve the development of leisure agriculture in the surrounding area, promoting the full prosperity of local farmers.

Table 2. 2017-2019 Gaochun District Reservoir and Lake Water Quality Evaluation.

\begin{tabular}{ccccc}
\hline $\begin{array}{c}\text { Lake and } \\
\text { Reservoir }\end{array}$ & $\begin{array}{c}\text { Lake or Reservoir } \\
\text { Section }\end{array}$ & $\begin{array}{c}\text { Water Quality } \\
\text { in 2017 }\end{array}$ & $\begin{array}{c}\text { Water Quality } \\
\text { in 2018 }\end{array}$ & $\begin{array}{c}\text { Water Quality } \\
\text { in 2019 }\end{array}$ \\
\hline \multirow{4}{*}{ Gucheng Lake } & Laket & III & II & II \\
& Dahu & III & II & II \\
& Xiaohu & III & II & II \\
& Yinghu Taoyuan & III & II & II \\
Longdunhe & Hongshazui & II & II & II \\
Reservoir & Longdunhe & II & III & II \\
& Reservoir & II & III & II \\
Sheshan & III & III & II \\
& Lake inlet & II & II & II \\
& Lake outlet & III & III & II \\
& Huxin & III & III & II \\
\hline
\end{tabular}

\subsection{Social Atmosphere}

With the increase of the social publicity of the RCS, a strong atmosphere that all citizens are involved participating in water management and protection has been created. Take one case study in Deqing County, Huzhou City, Zhejiang Province, as an example. According to field research, by the end of February 2020, more than 53,000 people have been registered as river chiefs, among which more than 28,000 have participated in river inspections. Since the promotion of the platform, the nominated chiefs have been participating in river inspections more than 530,000 times, which has indeed effectively improved the awareness of the public and the ability to participate. With the innovation of public participation modes and mechanisms such as Green Currency, the enthusiasm for public participation 
has increased. A total of 8.26 million green currencies have been issued of which over 4.97 million have been exchanged, which has effectively improved the consciousness and effectiveness of participating in water environment governance and alleviated the pressure on the administrative river chief. According to the survey results of the people's satisfaction with the RCS in Zhejiang Province, the score and ranking of Deqing County have increased significantly, as shown in Table 3.

Table 3. Crowd satisfaction scores and rankings of the RCS in Deqing County.

\begin{tabular}{ccccccccc}
\hline & Awareness & Participation & Support & Satisfaction & Confidence & $\begin{array}{c}\text { Sense of } \\
\text { Gain }\end{array}$ & $\begin{array}{c}\text { Total } \\
\text { Score }\end{array}$ & $\begin{array}{c}\text { Provincial } \\
\text { Ranking }\end{array}$ \\
\hline $\begin{array}{c}\text { Second } \\
\text { half of 2018 } \\
\begin{array}{c}\text { First half } \\
\text { of 2019 }\end{array}\end{array}$ & 80.00 & 56.50 & 97.30 & 87.70 & 93.27 & 85.20 & 82.76 & 53 \\
$\begin{array}{c}\text { Second } \\
\text { half of 2019 }\end{array}$ & 88.00 & 76.00 & 98.60 & 91.43 & 94.34 & 85.00 & 87.10 & 34 \\
\hline
\end{tabular}

\subsection{Government Departments}

Since the implementation of the RCS, Shi believed that the RCS was a bureaucratic operation mode based on authoritarianism [30], and Chen commented that the RCS showed obvious characteristics of "movement governance" in its operation [31]. The main manifestation is that the promotion and implementation of the responsibilities of the river chief are realized by a cumbersome and forced assessment method. The frequent assessment prompts the party committee and the government to interrupt the conventional mechanism and concentrate the efforts and attention of all parties to complete a certain task. But in practice, the RCS is essentially a top-down approach to mobilize various river governance resources. The interventions of high-level political and administrative authority to forcefully promote the effectiveness of river governance are obvious, and in the long run, they have a role in promoting environmental governance.

Public participation is mainly based on the information disclosure provided by the government, and the public makes choices that are beneficial to their interests. Public participation in the supervision of the construction of the RCS enables the public to have an equal dialogue with relevant departments and reach agreements on issues related to river and lake governance, thereby encouraging relevant departments to perform their duties. At the same time, by organizing the public, polluters, government authorities, and other stakeholders to participate in consultations, it is possible to fully express the interests of the public, improve the scientific nature of decision-making by functional departments, and promote the progress of the RCS.

\section{Issues and Suggestions for Public Participation of the RCS}

The stakeholder structures are especially complex when it comes to river management and restoration projects. According to Connif [32], 75\% of river restoration projects did not reach their minimal goals due to the lack of active stakeholder involvement. In Europe, it was difficult to motivate a representative crowd of people to participate in a time- and resources-consuming public participation process. Official agents waited until the plan had been approved before releasing it to the public, making the public believe that participation would not change the outcome of the plans [33].

Public participation is the inevitable result of the improvement of public environmental awareness and social democratization. Under the political system with Chinese characteristics, the general public has a high enthusiasm for participating in river and lake governance, which helps to improve the quality and efficiency of the RCS. However, there are still many problems in the process, including lack of public participation, lack of assurance of the authenticity and timeliness of environmental information disclosure, and the difficulty of obtaining timely feedback on public reports, etc. This is mainly due to the indifference to subject consciousness of the RCS, the wide range of interests in the implementation process, and the lack of long-term mechanisms of the RCS as a normal policy. 


\subsection{Reasons for Participation Failure: Consciousness, Interest, and Mechanisms}

\subsubsection{Indifferent to Subject Consciousness of the RCS}

The promotion of the RCS policy is still not enough. The level of grassroots participation is not extensive, or referring to the degrees of tokenism in the Arnstein ladder theory, most people stay in a passive education state of receiving leaflets, television, radio, and other propaganda channels. From September 24 to 26, 2019, the "Third National River Chief System Training Seminar" was held in Shaoxing, Zhejiang, sponsored by the Research and Training Center for River Chief System in Hohai University and Prof. Ju. A total number of 125 major party and government leaders from Beijing, Shanxi, Jiangsu, Guangdong, Zhejiang, and other provinces participated in the training seminar. Due to the wide range of ages and administrative levels, as well as the balanced gender ratio of the participants, the mode of the questionnaire can effectively reflect the recent public participation situation of the RCS. According to the statistical analysis of 120 on-site surveys on the relevant issues of On the Necessity of Public Participation in River Chief System Construction, 90\% of the trainees believe that public participation in the construction of the RCS is necessary, and no trainees think it is unnecessary. Regarding the reasons for public participation, $67.5 \%$ of the trainees believed that it is due to the serious social division and intensified conflicts of interest, $80 \%$ of the trainees believed that public participation can reduce the cost of government governance and ensure the continued growth of the RCS, and $85 \%$ of the trainees believe that public participation in the construction of the RCS can increase awareness of participation and consciously enhance participation behavior. However, the trainees' subject consciousness of public participation of the RCS is rather vague-75\% think that the general public should be included in the main body, $72.5 \%$ think that voluntary organizations should be included, $62.5 \%$ think that the mass media should be included, 52.5\% think that experts and scholars and public welfare lawyers should be included, and 52.5\% think that enterprises should be included. The above are all subjects of public participation. Additionally, the public's knowledge of river and lake governance and management is weak, and it is difficult to exert intrinsic motivation to participate in watershed management. According to the requirements of the Ministry of Water Resources on the construction of the RCS, public participation platforms have been established throughout the country, but there is a big difference between the number of registered and actual participants. The awareness of public participation is greater than the participation behavior, which reflects the challenges of public participation in the RCS.

\subsubsection{Wide Range of Interest}

In China, the central government is the policymaker, and the local government is the executor of the final implementation of the policy. How a policy is implemented depends on the attitude and ability of the local government [34]. At present, the disclosure of local government information is limited, there are other internal and external disclosures or selective disclosure under the control of the government, there are deviations or distortions in the level-by-level communication of public information [35], or there are cases where local governments make false reports based on their interests or repeatedly test indexes until reaching the standard before reporting data [36].

In practice, the decision-making right of public participation is difficult to implement, and information asymmetry leads to insufficient public understanding of information. The information asymmetry is mainly caused by the way government transmits documents and the media environment. The rules and regulations or documents formulated by the Chinese government follow a top-down, layer-by-layer, transmission path, and a lot of relevant information is "passed inside but not outside," that is, it is only transmitted within government agencies due to different levels of secrecy. This top-down communication path has two obstacles to fully conveying information. First, governments at all levels will act as "information filters." After balancing their interests, governments will filter out information that is not good for them. Governments often re-form operational policies for work convenience on the one hand and for the pursuit of benefits on the other hand, which can not only deceive higher-level 
governments but also omit information. Second, when information lags, the public cannot receive it on time, which restricts the paths of participation.

Complete public participation includes plan participation, process participation, end participation, and behavioral participation. The public participation of the RCS practice mainly focuses on end participation, supervising the implementation of the RCS. The responsibility in policy formulation, policy implementation, and performance appraisal still belongs to government-dependent public participation [37]. According to the survey data of Jiangsu Province in 2018 [38], the success of channels for the public to understand the RCS are $44 \%$ for public signs, $13 \%$ for publicity boards, $12 \%$ for the Internet, TV, and slogans, and 7\% for other channels. However, updates for RCS billboards are slow, and the telephone number of the river chief on the billboard is often out of service or unanswered.

\subsubsection{Lack of Long-term Mechanisms}

At present, the ways and levels of public participation in the construction of the RCS vary widely across the country. Most regions can only satisfy the public's right to know and are limited to creating a sufficient atmosphere. It is difficult to participate in decision-making and implement democratic supervision, and there is a lack of communication and feedback mechanisms for public reports. The assessment mechanism is primarily the internal assessment of the administrative system carried out by superiors to subordinates, seldom reporting criticisms, but commending a large number of outstanding river chiefs thereby driving self-praise and self-assessment within the organization. In essence, the RCS still belongs to the rule of man, not the rule of law [39], and the rule of man will have the randomness of decision-making and the uncertainty of behavioral consequences. The river chief needs to fully mobilize government and social resources through centralization and implement decisions in the shortest time, which greatly improves governance efficiency. However, centralization itself will easily deviate from the will of the public due to the interests of all parties. Once there is a lack of an absorption mechanism for public opinions, it is easy to cause the consequences of actions to be out of the way of the people. Additionally, sometimes the degree of the rule of man does not entirely depend on the personal wishes of the river chief and is also limited by local economic development [40]. Water governance is only one of the many responsibilities undertaken by the local government. If too many resources are invested in it, it will reduce investment in other public affairs, so economic development still takes precedence over environmental governance in some regions [41]. This affects public power and long-term governance, inevitably demanding a long-term mechanism to guarantee public participation.

\subsection{Suggestions for the Promotion of the RCS}

\subsubsection{Improve Public Participation Capability}

To improve public participation in the RCS, the first step is to improve participation ability. Whether it is an expert in Gulou District of Nanjing City or a municipal social supervisor in Tianjin, participants are required to have a certain degree of professional ability. Whether the public can effectively participate in the RCS is currently affected by their own ability to a certain extent [34]. The survey found that the higher the level of education and the higher their understanding of the RCS, the stronger their willingness to participate. This means that only by improving the public's ability can we further implement public participation in the whole process [42].

(1) Strengthen exchanges and cooperation with universities and training units, such as relying on the Research and Training Center for River Chief System of Hohai University to carry out special training seminars on the RCS to improve public participation awareness and practice, train qualified river, lake, and ecological environment protection teams, and provide a talent foundation for the construction of the RCS.

(2) Strengthen the guidance of voluntary organizations with strong professional ability, organization ability, and execution ability, actively carry out various publicity activities, improve the 
public knowledge level, provide an organized channel for public participation, and explore and absorb community members with a certain professional capacity.

\subsubsection{Implement Public Participation in the Process}

The implementation of the RCS relies too much on administrative power and is vulnerable to rent-seeking and corruption [35,36]. River and lake governance cannot rely solely on the power system, and social forces cannot be ignored or underestimated [31]. In addition to investigating and supervising the effects of river governance, the public should also fully participate in the formulation and implementation of RCS decisions [43]. Moreover, the evaluation of the RCS should take public evaluation as an important reference index [44]. Stakeholders should be organized to listen to the report of the river chiefs, and score points on the spot to make the evaluation process more transparent and the evaluation result more objective [45]. As stakeholders, the public will inevitably accept the influence of the RCS construction directly or indirectly. At present, it is necessary to change the situation that the public participation process of RCS construction mainly focuses on terminal participation and passive participation, while avoiding the formality.

(1) Decision-making: In the process of formulating the work plan, "One River, One Policy," and the demonstration and preparation of various river and lake protection and governance plans, relevant departments should invite public representatives and relevant stakeholders to participate in hearings, forums, and seminars to ensure the public's collaborative participation in decision-making and implementation.

(2) Management and protection: The government should encourage the public to participate in the operation and maintenance of rivers and lakes, undertake the cleaning and maintenance of certain river sections or water bodies in front of and behind houses, and volunteer to carry out river and lake cleanings and inspections.

(3) Supervision: Strengthen the construction of supervision channels such as the billboard of the RCS and WeChat official account of the RCS. Expand the exposure of RCS through regional webpages, forums, radio stations, television stations, newspapers, etc., to expand the role of the mass media in public opinion in the construction of the RCS.

(4) Evaluation: The evaluation and accountability system of the river chief should consider not only the effectiveness of governance but also the satisfaction of the public. The relevant government departments should increase public participation in government performance evaluation and assessment to put pressure on the government and its functional departments, forcing them to further open and accept public participation.

\subsubsection{Build a Long-term Public Participation Mechanism}

The higher the public's satisfaction with the disclosure of water environment information, the stronger the public's willingness to participate [42]. However, it is far from enough to provide supervision channels. What is more important is to establish a feedback mechanism to ensure that every complaint can receive an effective response from the competent authority [46]. In addition, strengthening the incentives and feedback for public participation can ensure long-term public participation enthusiasm [47]. To fully express the real interests of the public, promote the improvement of the overall governance level of the society, and ensure the effectiveness of the RCS, there is an urgent need to build a long-term public participation mechanism.

(1) Improve the water environment information disclosure mechanism. Environment information disclosure is a prerequisite for effective public participation. The disclosure conditions, time, content, and form of the information must be clarified, and the public should be given the right to apply for information disclosure and ensure that the information disclosed is true. If the government does not act or falsifies information, it should be held accountable.

(2) Improve the public interest litigation mechanism and feedback mechanism. It is necessary to promptly investigate and deal with violations of the water environment reported by the public and 
provide timely feedback on the public's relevant opinions on river and lake governance. This ensures that each item can be effectively responded to. The case handling rate and subsequent public satisfaction should be included in the evaluation of the RCS.

(3) Improve the public participation incentive mechanism. The essence of the incentive mechanism operation mode is profit-driven so that participants can not only obtain certain economic benefits but also enjoy the ecological benefits brought by the treatment of river and lake environments. In the short term, various types of activities, such as award-winning QandA and award-winning short video collection, can be carried out. In the long-term, models of award-winning complaints in Guangzhou City and ecological green currency in Deqing County can be used for reference.

(4) Activate the private investment mechanism. Use social capital to alleviate the shortage of water environment governance in all aspects, including not only financial investment but also technology, equipment, information, and talents provided by relevant scientific research institutions and environmental protection organizations. This can guide the public to participate in PPP projects with the aggregation of idle capital, ease the financial pressure of local governments, and promote the public to actively participate in water environment governance actions.

The success of the RCS is based on the strong financial support of the local government, which is why the RCS has reached a more profound effect in more developed areas. It may be difficult for underdeveloped regions to effectively provide such support for water governance, which requires the supplement of public power. Therefore, for underdeveloped countries or regions, the advantages of the RCS can be learned to establish a system which could meet the local condition. The awareness and ability of the public to participate should be further enhanced to make river and lake governance deeply rooted in the hearts of the public. For countries or regions with a medium economic level, the local governments should first implement the RCS or apply the development of the local system to make it not prescriptive but substantive, and explore practical ways of co-governance with the public. For more developed regions, relevant legislation can be added and relevant systems and mechanisms can be established to implement the whole process of public participation in river and lake governance, focusing on the long-term effectiveness of the system and public participation.

\section{Conclusions}

Studies show that public participation has a strong theoretical basis, and it has beneficial applications in water environmental protection, water pollution control, and water conservation. The RCS, an innovative system in China, is necessary to harness and utilize public participation effectively. The public is directly affected by the construction of the RCS and is a direct stakeholder of environmental interests. Therefore, they have the right and obligation to participate in the whole process of construction of the RCS, and also supplement and supervise the performance of the duties of river chief and related departments-they have the absolute right to check the effectiveness of governance. We have summarized practical work case studies in more than three years since the full implementation of the RCS. We conducted an effective review of the innovative models of public participation, which are mainly manifested in the innovation of supervision and management mode, the participation working mechanism, the social propaganda method, and the incentive feedback mechanism. Although the public participation of the RCS has achieved some positive results, there are still many problems in the implementation process. The current problems are mainly due to the subject consciousness of the RCS, the wide range of interest, and the lack of long-term mechanisms. It is necessary to further improve public participation capability, implement public participation in all parts of the process, build a long-term public participation mechanism, and maximize public flexibility and efficiency. Public participation is a requirement for creating a "co-construction, co-governance, and sharing" RCS. Innovations in all aspects of public participation in the construction of China's RCS will provide useful insights on water environment governance. 
Author Contributions: Conceptualization, C.W. and M.J.; data curation, C.W., M.J. and L.W.; writing-original draft preparation, C.W.; writing-review \& editing, L.W., X.G. and C.J. All authors have read and agreed to the published version of the manuscript.

Funding: This research was funded by the Major Projects of National Social Science Fund of China, grant number 19ZDA084 and 16ZDA046 and the Third-party Assessment and Evaluation Program of Fully Implementation of the River (Lake) Chief System in Hebei Province, grant number 820035716.

Acknowledgments: We wish to thank the Major Projects of National Social Science Fund of China (19ZDA084 and 16ZDA046) and the Third-party Assessment and Evaluation Program of Fully Implementation of the River (Lake) Chief System in Hebei Province (820035716) for the partial support of this work.

Conflicts of Interest: The authors declare no conflict of interest. The funders had no role in the design of the study; in the collection, analyses, or interpretation of data; in the writing of the manuscript, or in the decision to publish the results.

\section{References}

1. Molle, F.; Wester, P.; Hirsch, P. River basin development and management. Water for Food-Water for Life: A Comprehensive Assessment of Water Management in Agriculture. Int. Water Manag. Inst. 2007, 585-625.

2. Wang, Y.H.; Chen, X.N. River chief system as a collaborative water governance approach in China. Int. J. Water Resour. Dev. 2020, 36, 610-630. [CrossRef]

3. Wang, L.F.; Tong, J.X.; Li, Y. River Chief System (RCS): An experiment on cross-sectoral coordination of watershed governance. Front. Environ. Sci. Eng. 2019, 13. [CrossRef]

4. Tang, Y.S.; Zhao, X.Y.; Jiao, J.L. Ecological security assessment of Chaohu Lake Basin of China in the context of River Chief System reform. Environ. Sci. Pollut. Res. 2020, 27, 2773-2785. [CrossRef] [PubMed]

5. Liu, H.; Chen, Y.D.; Liu, T.; Lin, L. The River Chief System and River Pollution Control in China: A Case Study of Foshan. Water 2019, 11, 1606. [CrossRef]

6. Wu, D.; Cao, S.Q.; Kang, X.; Wang, H.J.; Liu, S.; Xu, H.Y. Status evaluation and prospect of water governance in China. Adv. Sci. Technol. Water Resour. 2019, 39, 7-14.

7. Xu, X.; Wu, F.P.; Zhang, L.; Gao, X. Assessing the Effect of the Chinese River Chief Policy for Water Pollution Control under Uncertainty-Using Chaohu Lake as a Case. Int. J. Environ. Res. Public. Heal. 2020, 17, 3103. [CrossRef]

8. She, Y.; Liu, Y.B.; Jiang, L.; Yuan, H.X. Is China's River Chief Policy effective? Evidence from a quasi-natural experiment in the Yangtze River Economic Belt, China. J. Clean Prod. 2019, 220, 919-930. [CrossRef]

9. Tu, Z.G.; Deng, H.; Gan, T.Q. The Logic of Public Participation in Environmental Governance in China: Theory, Practice and Pattern. J. Huazhong Norm. Univ. (Humanit. Soc. Sci. ) 2018, 57, 49-61.

10. Polanyi, M. The Logic. of Liberty; University of Chicago Press: Chicago, USA, 1951.

11. Mills, C.W. The Power Elite; Oxford University Press: USA, 1956.

12. Arnstein, S.R. A Ladder Of Citizen Participation. J. Am. Inst. Plan. 1969, 35, 216-224. [CrossRef]

13. Freeman, R.E. Strategic Management: A Stakeholder Approach; Pitman: Boston, USA, 1984.

14. Selznick, P. TVA and the Grass Roots: A Study in the Sociology of Formal Organization; University of California Press: Berkeley, CA, USA; Los Angeles, CA, USA, 1949.

15. Garda, C.; Castleden, H.; Conrad, C. Monitoring, Restoration, and Source Water Protection: Canadian Community-Based Environmental Organizations' Efforts towards Improving Aquatic Ecosystem Health. Water 2017, 9, 212. [CrossRef]

16. Euler, J.; Heldt, S. From information to participation and self-organization: Visions for European river basin management. Sci. Total. Environ. 2018, 621, 905-914. [CrossRef] [PubMed]

17. Ananga, E.O.; Njoh, A.J.; Pappas, C.; Ananga, G.O. Examining the relationship between community participation and water handling hygiene practices in the informal neighborhoods of Kisumu, Kenya. Habitat Int. 2017, 62, 1-10. [CrossRef]

18. Gera, W. Public participation in environmental governance in the Philippines: The challenge of consolidation in engaging the state. Land Use Policy 2016, 52, 501-510. [CrossRef]

19. Li, Y.H.; Tong, J.X.; Wang, L.F. Full Implementation of the River Chief System in China: Outcome and Weakness. Sustain. 2020, 12, 3754. [CrossRef]

20. Environmental Information Disclosure Measures (Trial). Available online: http://www.mee.gov.cn/gkml/zj/j1/ 200910/t20091022_171845.htm (accessed on 11 April 2007). 
21. Environmental Protection Law of People's Republic of China. Available online: http://www.mee.gov.cn/ ywgz/fgbz/fl/201404/t20140425_271040.shtml (accessed on 25 April 2014).

22. Measures for Public Participation in Environmental Protection. Available online: http://www.mee.gov.cn/ gkml/hbb/bl/201507/t20150720_306928.htm (accessed on 13 July 2015).

23. Measures for Public Participation in Environmental Impact Assessment. Available online: http://www.mee. gov.cn/gkml/sthjbgw/sthjbl/201808/t20180803_447662.htm (accessed on 16 July 2018).

24. Action Plan for Prevention and Control of Water Pollution. Available online: http://www.gov.cn/zhengce/ content/2015-04/16/content_9613.htm (accessed on 16 April 2015).

25. Opinions on Full Implementation of the River Chief System. Available online: http://www.gov.cn/xinwen/ 2016-12/11/content_5146628.htm (accessed on 11 December 2016).

26. Fu, S.M.; Li, W.P. “River Chief System” needs public supervision. Environ. Prot. 2009, 22-23.

27. Ma, P.C.; Zhu, Y.C. Research on Public Participation Model in Rural Water Environment Governance during the Practice of River Chief System. J. Huazhong Agric. Univ. (Soc. Sci. Ed.) 2020, 29-36.

28. "Xiao Yuer Patrol the River" WeChat Mini Program is now online! Available online: https://mp.weixin.qq. com/s/PqliqNSXvXRTWcNJ-YB7Iw (accessed on 15 November 2019).

29. Environmental Quality Standards for Surface Water. Available online: http://www.mee.gov.cn/ywgz/fgbz/bz/ bzwb/shjbh/shjzlbz/200206/t20020601_66497.htm (accessed on 1 June 2002).

30. Shi, Y.C. The Normative Construction of the "River-Director" System for Watershed Environment Governance: From the Two-fold Perspectives Based on Legal and Political Systems. Mod. Law Sci. 2018, 40, 95-109.

31. Chen, T. Generalization of Governance Mechanism: An Analytical Dimension of the Reproduction of River Chief System. J. Hohai Univ. (Philos. Soc. Sci.) 2019, 21, 97-103.

32. Connif, R. Rebuilding the Natural World: A Shift in Ecological Restoration. Available online: https:/e360.yale. edu/features/rebuilding_the_natural_world_a_shift_in_ecological_restoration (accessed on 17 March 2014).

33. Heldt, S.; Budryte, P.; Ingensiep, H.W.; Teichgräber, B.; Schneider, U.; Denecke, M. Social pitfalls for river restoration: How public participation uncovers problems with public acceptance. Environ. Earth Sci. 2016, 75, 1053. [CrossRef]

34. Wang, Y.N.; Cao, H.L. Public Participation in the Implementation of "System of River-Leader": How Possible and Achieved-A Case Study of "Assistant of River-Leader" in Xiangtan City. Soc. Sci. Res. 2019, 129-136.

35. Wang, Y. The Paradox of "River Chief System" in Water Environment Management and Its Resolution. West. Law Rev. 2015, 1-9.

36. S.F., L.; Yu, H. Current Assessment Situation of River Section and Recommendations for Measures. J. Environ. Manag. Coll. China 2019, 29, 14-17.

37. Huang, Q.D.; Xu, J.J. Rethinking Environmental Bureaucracies in River Chiefs System (RCS) in China: A Critical Literature Study. Sustainability 2019, 11, 1608. [CrossRef]

38. Cheng, Y.; Wu, Q.F. Studies on social dimension of public signs for river chief system. China Water Resour. 2019, 60-62.

39. Wang, C.F. The specific form of the local people's government responsible for the water environment quality within its jurisdiction-the legal interpretation of the "River Chief System". Environ. Prot. 2009, 20-21.

40. Mao, H.; Wang, L. Environmental Kuznets Curve Test of Industrial Pollution-An Empirical Study Based on China's Inter-provincial Panel Data from 1998 to 2010. Macroeconomics 2013, 89-97.

41. Li, J.; Shi, X.; Wu, H.Q.; Liu, L.W. Trade-off between economic development and environmental governance in China: An analysis based on the effect of river chief system. China Econ. Rev. 2020, 60, 101403. [CrossRef]

42. Yao, W.J.; Song, X. Investigation on the current situation and analysis on the willingness of public participation in river chief system. China Water Resour. 2020, 41-43.

43. Kan, L. Research on Innovation of River Chief System from the Perspective of Holistic Governance-Taking Jiangsu as an Example. China Rural Water Hydropower 2019, 39-43.

44. He, Q. "River Administrator" System from Perspective of Environmental Law. Public Adm. Law 2011, 78-82.

45. Zhang, C.L.; Li, Y.M.; Qin, H.B.; Chen, W.Y.; Hao, L.; Qiao, H.J. Suggestions on further perfecting river chief system to promote river and lake management in China. China Water Resour. 2019, 13-15.

46. Zhang, Y.Y. River Chief System: Advantage and Disadvantage, Argument and Improvement. Environ. Conform. Assess. 2019, 11, 93-98. 
47. Lei, M.G. Mechamism and Institutionalization of Citizen Participation in the Watershed Treatment: The Mode of Double-River-Chief-An Example of Xiangjiang River Governance Practice. Environ. Prot. 2018, 46, $63-66$.

Publisher's Note: MDPI stays neutral with regard to jurisdictional claims in published maps and institutional affiliations.

(C) 2020 by the authors. Licensee MDPI, Basel, Switzerland. This article is an open access article distributed under the terms and conditions of the Creative Commons Attribution (CC BY) license (http://creativecommons.org/licenses/by/4.0/). 